\title{
Conclusion: Are Rising Powers Breaking the Peacebuilding Mold?
}

\author{
Charles T. Call and Cedric de Coning
}

\section{INTRODUCTION}

The growing international profile of countries like India, Indonesia, Brazil, Turkey, and South Africa has drawn considerable attention in scholarly and policy circles in the past decade (Carmody 2013; Fernández Jilberto and Hogenboom 2010; Mody 2011; Vieira and Alden 2011). Each of these countries has deliberately sought to strengthen its position in regional affairs and in global institutions (Flemes 2007; Hurrell 2006; Schirm 2012). They are all democratic regimes that have (along with China and Russia) opened up their markets in the past two decades and experienced dramatic economic growth. These countries have grown their middle classes and reduced the portion of those in extreme poverty.

These rising powers have also become notably more active in facilitating the economic development of other, less powerful, countries. India's

C.T. Call $(\bowtie)$

School of International Service, American University, Washington, DC, USA

C. de Coning

Norwegian Institute of International Affairs, Oslo, Norway

Peacekeeping and Peacebuilding Unit, ACCORD, Durban, South Africa

(C) The Author(s) 2017

C.T. Call, C. de Coning (eds.), Rising Powers and

Peacebuilding, Rethinking Peace and Conflict Studies,

DOI 10.1007/978-3-319-60621-7_10 
development cooperation increased fourfold in the decade between 2003-2004 and 2013-2014 (Mullen 2013). India and Brazil created new agencies dedicated to development cooperation, and South Africa is in an advanced stage of creating a new agency, but it has been actively supporting other African countries since at least 2000 through the African Renaissance Fund (Besharati 2013). Brazilian development cooperation, for instance, rose from US\$160 million in 2005 to over US\$900 million by 2010 (Leite et al. 2014, 7). Over that period, its technical cooperation grew almost fourfold and its humanitarian cooperation exploded from less than \$US1 million to US\$161 million (Leite et al. 2014, 7). Admittedly, these totals remain small compared to traditional donors, and financial or political crises in Brazil, Turkey, and South Africa call into question the sustainability of even this level of cooperation. Nevertheless, these expanded development roles are politically meaningful for rising powers and their development partners.

Less attention has been devoted to the roles these rising powers play in facilitating peace processes and supporting efforts to prevent and end wars in other countries. Since 2002, each of these countries launched efforts at what we may call "peacebuilding." Turkey, for instance, played a high-profile role in mediation and post-war recovery efforts in Somalia. South Africa has supported peace efforts in Burundi and the Democratic Republic of the Congo (DRC), just as Indonesia has supported peace processes in the Philippines and Myanmar. India is the fourth-largest donor in war-torn Afghanistan. Brazil has played leading roles in the United Nations (UN) Peacebuilding Commission and in UN peace missions in Haiti and the Guinea-Bissau.

All of these rising powers have emphasized the comparative advantages they bring to peacebuilding over traditional Western actors. Turkey and Indonesia, for example, see themselves as regional examples of transitions to secular democracy in Muslim majority countries. India and South Africa believe that their own anti-colonial struggles and liberation position them well to share experiences and capacities in an egalitarian and respectful manner.

Yet, little comparative and systematic research has been carried out on the peacebuilding roles of these new actors. New research on development roles has not extended as far into the roles in their new programs in post-conflict countries or to advance peace in fragile or war-torn societies (de Carvalho and de Coning 2014; Mathur 2014; Richmond and Tellidis 2013). This chapter offers some conclusions from the research carried out 
in 2015 and published in this book by our contributing partners from India, Indonesia, South Africa, and Turkey on their specific approaches to peacebuilding. We added a contribution on Brazil as well. The chapter begins with some of the conceptual findings of the book as regard to the very definition of peacebuilding. It then highlights some of the commonalities across these countries' policies and peacebuilding activities, followed by an analysis of some of the differences among the countries and implications for ideas and the practice of peacebuilding. We believe that these conclusions might serve as hypotheses about the new role of emerging powers in the relatively new field of peacebuilding.

\section{Concepts: Different States, Different UNDERSTANDINGS}

\section{Rising Powers, Development Partners}

This book focuses on the role of what we call "rising powers" in and around peacebuilding. No term adequately captures the group of states examined here. We initially referred to "emerging powers," a term that derives from "emerging markets." However, countries like Brazil, Turkey, and India eschew this label since they either are or have in the past been powers in their own right. The term "middle powers" also is appropriate for some of these states, but derives from a realpolitik framework that emphasizes traditional military prowess and aspirations that do not reflect the way that these countries see themselves today. Countries such as Brazil and Indonesia reject a world order assigning position based on military power, and see their contribution as helping address global problems (de Carvalho and de Coning 2014).

"Rising powers" capture the role of Indonesia, South Africa, Brazil, India, and Turkey better than "emerging" since it reflects recent movement with a positive connotation. Turkish officials are more comfortable with a characterization that conforms to their self-image of increased regional influence. Nevertheless, diplomats of countries like Indonesia are uncomfortable with "rising power" since they do not wish to seem to elevate themselves above other countries in any way. Here, we use rising power to refer to the countries that have successfully sought to exercise a strategic influence in their regions and in multilateral fora. Although 
countries such as Russia, Nigeria, Mexico, and Egypt might warrant "rising power" status, we focus on countries that have played a particular role on peacebuilding issues-India, Indonesia, Turkey, Brazil, and South Africa.

\section{Peacebuilding}

One important finding of the book is a concept of "peacebuilding" among policy circles in rising powers that diverges in clear ways from how the concept is used by traditional donors and the UN system. In our initial conversations, project partners in India, Indonesia, South Africa, Turkey, United States, and Norway determined that we would not pre-determine a specific definition of "peacebuilding," but would let each nationally focused line of research articulate its own definition based on the policy context of that country. The main guidance agreed among the partners was that some "theory of change" needs to exist that reflect how a given activity is intended to influence peace and order, for it to be considered "peacebuilding." Thus, we did not beforehand seek to restrict the conceptual time frame to post-conflict, or limit its content in ways that excluded economic development activities or mediation support efforts or even humanitarian projects, so long as some theorized link to peace outcomes existed. What interested us was how policy communities in rising powers thought about peacebuilding and defined it themselves. We also did not pursue notions of peacebuilding defined as independent variables, that is, we were interested in peace-related outcomes rather than the impact of peacebuilding activities or their success.

Peacebuilding, it turns out, is not a clearly defined or well-developed concept in policy circles of virtually any rising power. In fact, it is rarely used in the domestic discourse of the rising powers studied. When it is used, it is most often in connection with discussions of UN peacebuilding. Domestically, the preference seems to be for a wide range of concepts that are descriptive of the activities undertaken, for example, technical exchanges, training, mediation, rather than of the overall intent. Rarely is an attempt made to group several such activities together under an overarching concept like peacebuilding. The term is more widely used, with a shared understanding, by some (e.g., Brazil) than others (e.g., India), often as a result of exposure to and active participation in multilateral fora such as the UN Peacebuilding Commission. Yet even Brazilians use the term in slightly different ways, depending on if it is used in the corridors 
of the UN, in the Ministry of Foreign Relations, or in mobilizing large infrastructure projects. In Turkey, the term connotes some link to ending human suffering in war-torn societies, and in South Africa officials are more likely to refer to post-conflict reconstruction.

Peacebuilding offers an example of concepts shaped by international organizations and their interaction with domestic bureaucracies. The traditional (viz., OECD) donors have shaped the Western understanding of peacebuilding as largely a category of programmatic activity that is funded for a specific purpose, different from "normal" development, and thus exempted from some of its requirements. Thus, the need, from a donor logic, to differentiate between funds spent on peacebuilding versus development played an important role in conceptualizing what is and what is not peacebuilding. This element seems missing among the rising powers. Their bureaucracies have no need to distinguish peacebuilding from development, mediation, or other categories, since they are not subject to the Organisation for Economic Co-operation and Development (OECD's) Development Assistance Committee regulations. In contrast, rising powers are incentivized to keep the concept vague and flexible, partly to avoid battles over turf and resources among ministries and departments. In the case of peacebuilding, it would appear as if international organizations have shaped the discourse in rising powers more than the reverse.

Perhaps it is best to begin with how the concept is deployed in the UN system and among traditional donors and the European Union (EU), albeit with differences. The UN's concept of peacebuilding has evolved, from a narrow one focused on political aspects of post-accord, post-conflict processes toward a concept that encompasses state institution-building, economic recovery, national ownership, and, most recently, sustaining peace (Call and Collin 2015). Nevertheless, the UN concept, at least until very recently, tended toward top-down and state-centric approaches that emphasize political and security institution-building over civil society and long-term economic development. Among Western donors, the concept also shares a focus on political and security institution-building, with some economic activities, and a general focus on post-conflict recovery. The EU has a broader approach that emphasizes prevention. It uses "conflict prevention" and "conflict mitigation" alongside "peacebuilding," which "tends to be associated with a wide range of long-term development activities designed to promote structural stability, or with short-term actions with direct conflict prevention objectives" (quoted in Stamnes 2016, 3). 


\section{A More Holistic Concept}

Rising powers' concept of "peacebuilding" is closer to that of the EU but broader in time and content. The peacebuilding concept of the six rising powers studied in this book encompasses a broad swath of development and other activities in war-torn societies, as well as conflict prevention and mediation efforts in "pre-war" or peaceful societies seen as unstable. Thus, for them peacebuilding activities in war-torn societies extend to health projects, student exchanges, education support such as building schools, food security, infrastructure development of any sort, as well as political/ security cooperation like security advisers, mediation support, dialogue facilitation, and elections support. In their chapter, Nyuykonge and Zondi say, for instance, "In terms of peacebuilding support, South Africa has provided states with substantial assistance in the areas of good governance, dialogue and reconciliation, human resource and infrastructure development, policy implementation, economic development and trade, information sharing and exchange visits among South African dignitaries, as well as humanitarian assistance." India's concept is the broadest of the countries examined here, going beyond the others in breadth. For India, virtually all development in a war-torn society, or societies where conflict may arise, is considered peacebuilding. Singh's chapter quotes one Indian official as saying that the attempt to distinguish between peacebuilding and other development assistance is "academic hair-splitting," a view "shared by others" in New Delhi.

At the UN, there is a process underway that is broadening the concept. In 2016, building on a review of the UN's peacebuilding architecture, undertaken by an Advisory Group of Experts and a review of UN peace operations undertaken by a High-level Independent Panel, the Security Council and General Assembly adopted resolutions on the UN peacebuilding architecture that embraced a new concept of "sustaining peace," that comports more closely with that of rising powers.

The "sustainable peace" concept has been influenced by the process leading to the adoption of the UN's Agenda 2030 including approval of a broad set of sustainable development goals (SDGs) in 2015. Among this new set of goals, 36 targets refer to the negative influence of violence and instability, and Goal 16 specifically aims to promote peaceful and inclusive societies for sustainable development, provide access to justice for all, and build effective, accountable, and inclusive institutions at all levels (UN 2015). Although not well defined, "sustainable peace" moves beyond 
post-conflict contexts to prevention, and suggests a greater emphasis on economic foundations for longer-term peace and addressing underlying causes of conflict. It also represents a shift in focus to local agency, as it operates from the assumption that to sustain the peace, local social institutions need to have the resilient capacity to absorb tensions and shocks that would otherwise risk a lapse into violent conflict.

As Youssef Mahmoud and Andrea Ó Súilleabháin have noted, this new expansive definition recognizes that sustaining peace is an inherently political process that spans prevention, mediation, conflict management, and resolution. They argue that with the sustaining peace concept, the UN approach to peacebuilding now puts UN member states and their populations in the lead; it further puts politics and political solutions front and center, gives prevention an uncontested home, and leverages the UN's three pillars-human rights, peace and security, and sustainable development-in a mutually reinforcing way (Mahmoud and Ó Súilleabháin 2016).

The new UN Secretary-General António Guterres, who took office on 1 January 2017, has embraced these developments and has made prevention and sustaining peace a central theme of his office. In his first statement to the UN Security Council on 10 January 2017, he noted the strong support for an integrated approach that connects development, human rights, and peace and security in both the 2030 Agenda for Sustainable Development and the General Assembly and Security Council resolutions on sustaining peace. ${ }^{1}$ This broadening of the peacebuilding concept seems to fit well with the rising powers' approach that tends to be quite comprehensive and/or holistic, that is, inclusive of political, security, peace, justice, development, and economic elements. This broadening of the peacebuilding concept seems to fit well with the rising powers' approach that tends to be quite comprehensive and/or holistic, that is, inclusive of political, security, peace, justice, development, and economic elements.

Rising powers also see a closer link between humanitarian assistance and peacebuilding. This is the strongest in Turkey, where its efforts to support Somalia's response to famine in 2003 led to major peace-related initiatives in Somalia (Achilles et al. 2015; Tank 2013). But it is also present in other countries, such as Brazil, which saw its response in Haiti deepened after Hurricane Tomas hit that country in 2010, and South Africa that combined offers of humanitarian assistance to, for instance, Somalia, with a range of other initiatives aimed at conflict resolution and post-conflict reconstruction (Kok 2014; Nyuykonge and Zondi 2016; van Nieuwkerk 
2014). Alexandra argues in her chapter that the frequency of natural and other humanitarian emergencies in Southeast Asia makes it a fertile opportunity to open up work related to peace: "While humanitarian action, including disaster relief, is normally separated from peacebuilding efforts, in the context of Indonesia, humanitarian assistance has been utilized to pave the way to conduct peacebuilding." Following Cyclone Nargis in 2012, the Indonesian government and its Red Cross drew explicitly on the post-tsunami Aceh experience to dialogue with the Myanmar government about the importance of opening up to the international community, democratization, and addressing the conflict in Rakhine state involving the Rohingya.

\section{Institutional/Legal Incentives}

Divergent histories and legal/political contexts also shape the global South's broader concept of peacebuilding. In the West, the need to justify ODA in the OECD Development Assistance Committee (DAC) and national legal and parliamentary oversight contexts has resulted in the need to delineate between peacebuilding funding versus development funding versus humanitarian aid. Because rising powers do not share this same history, they can be more flexible in their approach to peacebuilding and are not under pressure to define or delineate it from "routine" development.

\section{Not Just Post-conflict}

Activities such as mediation support, dialogue facilitation, and cross-ethnic programs in non-war settings - which might be considered "peacemaking" and "conflict prevention" in the UN system-also fall under the rubric of "peacebuilding" for many rising powers. Indonesia's efforts to facilitate a peaceful political transition in Myanmar, apart from the peace processes involving ethnic rebel movements in that country, are nevertheless considered a major peacebuilding activity undertaken by Indonesian officials. Mediation support efforts like Turkey's in Somalia and Indonesia's in the Philippines are also considered peacebuilding by many (Martin 2010). Similarly, many Indonesian, Indian, and South African officials make no distinction between peacekeeping and peacebuilding. They find it puzzling to exclude from "peacebuilding" the extensive operations historically undertaken by these countries in peacekeeping, dating back decades (India remains one of the largest troop contributors in the world). For instance, 
in 2004, the South African minister of defense combined these approaches when she introduced the new concept of "developmental peacekeeping" (Madlala-Routledge and Liebenberg 2004). Some Brazilian officialsmainly those who have been posted to New York-routinely distinguish between peacekeeping and peacebuilding, but many in Brasília do not (Charles Call interview with MRE officials, August 2015, Brasilia).

\section{Context-Specific Usage}

A tension also seems to exist between how rising powers use the concept at the UN in New York versus how they use it at home in their capitals. At the UN, rising powers tend to use the concept in a way that comports with the UN definition, and, at least before the latest "sustaining peace" evolution of the concept, eschews prevention which may be seen as an incursion on sovereignty. However, in their own foreign ministries and in exchanges with think tanks and civil society, these governments tend not to use the term much. When they do, it is a concept that is more pragmatic, flexible, and all-encompassing of activities such as mediation support, direct mediation, peace-related economic development projects, and indeed any development and infrastructure projects in a post-conflict setting.

\section{Rising Powers' Peacebuilding Policies and Operations}

Rising powers' recent experiences and their own characteristics have shaped their motives for embarking on new or expanded efforts to advance peace in other countries. Their experience shows a combination of distinct values and principles that mutually reinforced strategic interests. All these countries sought more influence in their own regions and in global affairs. Their greater role in providing development cooperation and in peacemaking and peacebuilding efforts reflect a sense that such middle powers can and should play lead roles in handling international responses to specific countries. Turkey tried to mediate the very challenging war in Somalia and, in partnership with Brazil, a nuclear deal with Iran. South Africa sought to help bring stability to its continent partly to secure more stable environment for investment and trade. In the only UN peacekeeping operation in the Western hemisphere, in Haiti, Brazil sought and received command of the military forces in that country, a role sustained without interruption since 2004 (Santos and Cravo 2014). India's expansive support for Afghanistan's transition took place in the shadow of its rivalry with Pakistan. 
These rising powers have all eschewed unilateral military action, openly backing peacekeeping as a multilateral alternative, preferably with the consent of the host government. Their commitment to a less militarized world coheres with their comparative advantage of "soft power"- of which peacebuilding is one element-rather than traditional "hard" power of military troop deployments and operations. Civilian-led peacebuilding efforts offer a way to advance security objectives in a deliberately nonunilateral, non-militarized manner.

It is no coincidence that these efforts, and the expanded roles in development and peacebuilding, occurred on the heels of the crisis of legitimacy of the UN Security Council following the US invasion of Iraq without its consent in 2003. The elections of Recep Tayyip Erdoğan as prime minister of Turkey and of Luiz Inácio Lula da Silva as president of Brazil ushered in governments that sought more prominent and active roles in global politics. At times, these countries sought to alter the structure of global order, and at other times they sought to rise within that order (de Coning et al. 2015). South Africa, India, and Brazil campaigned for a revamped UN Security Council in which they would have permanent seats (McDonald and Patrick 2010; Pouliot and Therien 2015).

Material interests also drive investment and technical cooperation in risky war-torn environments. Abdenur and De Souza (2014) argue that development and peacebuilding interventions reflect direct economic gains as well as security or principled interests of rising powers. Brazilian diplomats acknowledge that opening markets in sub-Saharan Africa was a goal that converged with that country's concern to assist post-conflict Lusophone countries like Guinea-Bissau, Angola, and Mozambique (Charles Call interviews with various diplomats who requested anonymity, Brasilia, August 2015). China's access to raw materials and markets in Africa is an acknowledged benefit of its increased peacebuilding engagement.

Yet, interviews conducted for this book reveal that values and principles underlie choices to carry out peacebuilding in ways that reflect less hierarchy, less conditionality, less security-focus, and a greater commitment to longer-term accompaniment rather than urgent stabilization and exit. These motives and values are not the focus of this piece, but are relevant to the analysis that follows. Our aim here is rather to identify the main characteristics of these selected rising powers' approaches to peacebuilding, putting into relief their differences from traditional, Western approaches. It is important to note that these rising powers are democratic regimes whose policies may be even closer to Western approaches than nontraditional donors such as China, Russia, and the Gulf states. 


\section{Divergent Worldviews and Theories of Change?}

The different approaches of rising powers may best captured in the context of broader understandings about development, and especially what was once known as "political development"-that is, how developmental states emerge over time and through what historical processes, and how stable polities and regional arrangements emerge and are sustained. In concrete terms, these are distinct "theories of change" in peace processes, peacebuilding, and institutional development. The peacebuilding approach of traditional donors - embodied by the OECD - is focused on preventing lapses or relapses into violent conflict. While it recognizes that there may be deeper root causes at work that need longer-term attention, it tends to focus on addressing more immediate tensions that, if left unaddressed, can become triggers for violent conflict.

Recent best practice in the "traditional donor" approach in any given setting is that peacebuilding interventions need to be informed by a conflict analysis that seeks to map the conflict by identifying the main actors, the conflict drivers, the political economy of the conflict, and the political history of the conflict. ${ }^{2}$ This kind of technical analysis usually finds that conflicts are driven by political, social, and economic inequalities between groups. These groups are usually organized along ethnic, religious, or language identities, and the conflict is typically linked to one or more groups feeling marginalized, for instance, due to center-periphery inequalities. Economic actors and factors are not ignored, but are placed in the context of these group dynamics. They generally manifest an emphasis on the free flow of goods and services, especially capital. The traditional donor approach to peacebuilding in this context is typically aimed at trying to change the behavior of the political system that causes marginalization and inequality by introducing incentives that encourage greater political pluralism and political freedoms. It tends to focus on trying to address such inequalities in political processes and institutions, the civil service, the judicial and security sector, both by making these state institutions more representative of the population of a given country and by spreading state services to the periphery. The theory of change is that greater political access and participation will lead to greater social stability, which will be conducive to development and economic prosperity.

The rising powers seem to have a different theory of political, social, and economic change. Politics, development, and stability are seen as closely interlinked, with political complexity emerging in step with advances in 
development. Their experience suggests that the level of political competition that a society can manage peacefully is closely linked to the complexity of its social institutions, and thus its level of development. To ensure stability, political activity needs to be governed to stay within manageable levels, and the focus for social change should be on social and economic development. They argue that over time developmental progress enables a social system to become more political complex, and this enables a society to develop social institutions, which ultimately has to manifest in state institutions, to manage the political competition within society. ${ }^{3}$ This is why the peacebuilding approach of rising powers tends to focus on the development of state institutions and why they tend to focus on socioeconomic development.

These differences in their respective theories of change may help to explain why the rising powers and traditional donors have different approaches when it comes to, for instance, differentiating between peacebuilding and development, measuring results, or working with civil society. For instance, on civil society, while rising powers are concerned about the peaceful development of the whole society, and while it may be involved in projects that involve the community, it prefers to do so through the institutions of the state, because sustainable development and sustainable peace require the development of responsible state institutions. Fragmented power across state and social institutions will not, in this view, help move the country toward stability or institutional and economic development. Rising powers are concerned that working through non-governmental actors to deliver social goods undermine the development of state institutions and thus ultimately delay and undermine self-sustainable peace and development. They thus prefer to work through state institutions and in this way try to stimulate and develop those institutions they view as most important to ensure self-sustainable peace and development.

When it comes to results, the lack of interest that rising powers seem to show for the kind of monitoring and evaluation systems favored by traditional donors could be partly explained by their theory of change that anticipate slow maturing long-term results. Rising powers realize that their approach to peacebuilding generates change over the medium- to long-term. While they may engage in community development (see India chapter) and other initiatives aimed at more short-term needs, their goal is to lay the foundation for peaceful development. They regard their peacebuilding support as successful as it results in steady progress toward selfsustainable peace. Rising powers thus tend to be less concerned about the 
politics and setbacks of the day. They prefer stability, so that the longer-term trajectory to development is not disrupted. They thus prefer to focus on infrastructure, agriculture, education, and public administration, because they argue that these are the basic socio-economic and governance capacities that any society and state need, regardless of the politics of the day. They also believe that infrastructure that links the periphery to the center, and education and agricultural development that uplifts all societies, will contribute to alleviate inequalities over the medium- to long-term. While this is not something they are concerned about monitoring in the shortterm, they do, at times, articulate such goals (see Myanmar case study) that can be evaluated over time. At the same time, there does seem to be a growing interest among rising powers in the results frameworks employed by the traditional donors. The development agencies in Brazil, India, and South Africa have exchanges with their counterparts among the traditional donors. They seek to improve their tools and techniques, including their monitoring and results systems. This interest is driven by a functional or technical interest in improving practice, not by changes in their overarching theory of change.

The primacy of stable development in the approach of the rising powers to peacebuilding may also explain why they do not feel the same need as traditional donors to differentiate conceptually or in practice between peacebuilding and development. For the rising powers progress in the area of socio-economic development automatically means progress toward peacebuilding. Politics, development, and stability are understood as closely interlinked, with political complexity emerging in step with advances in development. The traditional donors have their own unique historic context within which development originated. As peacebuilding is a fairly recent addition, and as it differed in important aspects from development, traditional donor bureaucracies felt the need to explain how peacebuilding and development are different from each other. Growing impulses in Western capitals, especially legislatures, to monitor and measure the activities and outcomes of development assistance also drove distinctions to clarify distinctions between security-related and development-related efforts. This was driven in part by human rights concerns, and partly by bureaucratic tendencies to protect turf and budgets. The rising powers do not have these same bureaucratic pressures to differentiate between peacebuilding and development.

Another reason why the rising powers may have the "luxury" of a peacebuilding approach that is grounded in longer-term development and 
stability is because they do not feel responsible, to the same degree as traditional donors, for the day-to-day management of global peace and security. Rising powers regard the day-to-day maintenance and management of international peace and security as the responsibility of the UN and they contribute to that responsibility through peacekeeping and other contributions to the UN. They regard the UN Security Council, and the UN and related institutions, such as the Bretton Woods institutions, as dominated by Western powers, and thus view these powers as primarily responsible for the day-to-day management of international peace and security. In addition, they project a solidarity to humanity that leads them to engage in bilateral peacebuilding and development; however, this is not driven by, or understood as, a contribution to maintaining or managing the global order on a day-to-day basis. Rather it is seen as contributing to the medium- to long-term human development.

Below are some of the core characteristics our book has identified of rising powers' new approaches to peacebuilding.

1. Each rising power's approach to peacebuilding is shaped by its own identity and recent historical experiences.

Western powers' history and values shape the content of their development and peacebuilding approaches, so it is unsurprising that rising powers' experiences should influence theirs. However, rising powers tend to explicitly cite their own experiences in their policy statements and in their dialogues with partner countries. Thus, Turkey's peace efforts emphasize its recent experience in democratization and its unusual position as a secular Muslim democracy. India's peacebuilding is informed by its own postcolonial struggle for independence, with an emphasis on sovereignty and development, rather than security. As Singh says in his chapter, "India shares her experiences of democracy, pluralism and tolerance with the host countries, without interfering in their internal politics and social dynamics." South Africa's regional work advancing peace reflects the debt that the ANC-led government feels it owes to its African neighbors for their support during apartheid.

In her chapter, Alexandra points out that Indonesia's interactions with partners are shared "based on Indonesia's own experiences with democratic consolidation." Its Bali Democracy Forum invites Asia-Pacific leaders to share their experiences to foster international cooperation in peace and democracy. Alexandra finds that Indonesia's work on democracy is linked 
to its policy to advance the stability of Southeast Asia: its "experiences of democratic transition, which included installing the civilian government, returning the military to the barracks, and settling internal conflicts, have been considered valuable lessons which can be shared with other countries that are currently struggling with similar challenges." These lessons have shaped its relations with Myanmar more than discourse about stability or peace. The democratic character of these rising powers plays a special role in their peacebuilding policies. Indeed, recent democratization experiences are also seen as comparative advantages over traditional donors.

\section{Longer time horizon for peacebuilding.}

The UN and traditional donor approaches to peacebuilding have tended to focus on preventing relapse into violent conflict. This has resulted in a preoccupation with immediate risks and thus the short term. The UN approach until recently focused on "post-conflict" peacebuilding, rather than prevention, especially in forestalling relapse within six months to two years of war's end. Although the average length of UN peace operations grew from 5.62 years at the end of 1995 to 7.97 years by mid-2016, ${ }^{4}$ these operations rarely privilege "root causes" and have more minimalist aims of demobilizing combatants, building basic state institutions and supporting elections before withdrawal of UN missions and return to a "normal" development process.

By contrast, the rising powers seem to have a longer-term approach to peacebuilding that reflects some degree of strategic patience and historic perspective. Their theories of change are typically long-term, believing that addressing underlying causes of conflict, which are often economic in nature, are the soundest way to prevent violent conflict. Of our cases, India is most emblematic of this long-range perspective. Singh argues in his chapter that for current Indian policy, development activities are peacebuilding: "India has not made the same distinction between development assistance and peacebuilding activities that the traditional actors seem to make." India is proud to count its scholarships for Afghans to study in India as part of its contribution to peace there. Somalia's ambassador to Turkey praises Turkish scholarships for Somalis. Its investment in infrastructure like the "ring road" in Afghanistan is also seen as a key contribution to peace. The road is useful for internal and international commerce, and useful for defense forces' mobility. It is an investment to support an embattled allied government, and investment in both internal peace and 
in regional stability. Turkey similarly invested in the Mogadishu port and in key roads there. Indonesia explicitly emphasizes its slow, deliberate support for dialogue in places like the Philippines and Myanmar.

At the same time, we see a contradictory aspect of rising powers' approach. These countries tend to eschew the lengthy bureaucratic processes of traditional donors, relishing quickly visible projects that governments have explicitly requested and that the population can see. Turkey's road and ports projects in Mogadishu are a case in point. Turkish officials stress that other donors' red tape led to many delays, and the Turkish government quickly approved a road project and the gift of four boats for the coast guard that Somalis saw as immediate, concrete contributions. Rising powers also envision a long-term relationship with the partner country that involves diverse sets of support to help economic development reach a level whereby stability is enhanced. They are less concerned with the immediate outbreak of hostilities and more concerned with a slow progression toward economic growth and stability that will have positive effects for the rising power's own commercial interests and for regional stability.

3. Heightened concerns about national sovereignty, and thus national ownership.

The rising powers uniformly emphasize national ownership in their peacebuilding approaches, often in the context of the UN Charter principles of sovereignty and self-determination. When the UN Security Council considered invoking its authority under Responsibility to Protect to send in assistance over the objections of the Myanmar government, Indonesia argued forcefully against any action defying the government's will. According to Alexandra, "consent from the host country is a must" in Indonesia's approach to engaging with other countries. She goes on to argue that:

Indonesia's role is to support each country as it crafts its own peacebuilding process, rather than pushing it from the outside. This approach contributes to the establishment of a sense of national ownership that is critical to ensure the success of any peacebuilding effort.

Brazil, India, and Turkey have all underscored their emphasis on national ownership repeatedly. In 2012, for instance, India's acting Ambassador 
to the UN said that it is "important for the PBC [UN Peacebuilding Commission] to align its objectives with national priorities and ensure that all plans and programmes are implemented under national leadership and through national institutions so that gains are sustainable even if slow," (quoted in Singh's chapter). Over the past decade, a demand for greater national ownership from G7+ countries has converged with a similar stance among rising powers in the Global South to lead the UN, the EU and OECD countries to commit to national ownership in virtually all documents and discussions of peacebuilding.

The emphasis by emerging powers on sovereignty shapes their understanding of "national ownership." It means taking priorities first from the central government, and then also channeling resources through the state. For rising powers, this notion translates largely to accepting the government of the day as the embodiment of national ownership, with less emphasis on local or inclusive ownership. India's peacebuilding priorities in Afghanistan, for instance, are shaped very heavily by conversations between the Indian ambassador in Kabul and the Afghan president. Turkey reaches out more to local leaders, whose priorities determine how Turkish assistance will be used. Typically, rising powers do not invest in much broader consultations with lower level community leaders, civil society, or critics of the government in formulating priorities. They are concerned more about the capacity than the legitimacy of the partner state. Their vision is to invest in the long-term development of the state, regardless of the government of the day. In implementation, countries like India and Turkey may well then reach out to and meet with local beneficiary communities. Indian officials, for instance, seek warm relations of solidarity with partner countries and care about what local communities think of their programs and their effects. They may adapt their programs in response to dialogue with communities. However, in setting priorities, they principally and initially take their cues from the central government's preferences.

This approach contrasts with the growing understanding that Western donors have of "national" and "local" ownership that includes nongovernmental actors, especially civil society organizations representative of salient social groups based on ethnicity, gender, youth, and religion. Rising powers' views on peacebuilding comport less with the trend among intergovernmental organizations, Western donors and the new SDGs emphasizing "inclusive politics." 
4. A rejection of conditions on cooperation, reflecting a less securitized and more egalitarian vision of global order.

One of the consequences of values that seek to democratize the global order and of histories of colonial occupation is an emphasis on equality and mutual respect for partner countries. The implications of this posture go beyond a refusal to tell other countries what they should do to eschewing conditionality that has been and continues to be central to Western and traditional modes of aid and diplomacy. Rising powers openly reject conditioning their assistance on liberal political, democratic, electoral, or human rights benchmarks that have become the hallmark of North American and European assistance. As Singh points out in his chapter "Right from the outset, India's basic philosophy towards development assistance was that any aid/assistance would be demand driven, given without conditionalities, be administered in a decentralized manner and would not constrain the sovereignty of its partners in any way." Similarly Sazak and his co-authors argue that:

As often reiterated by Turkish Foreign Ministry, and intermediary organizations, Turkey does not discriminate on race, religion, language and gender, nor does it place political or economic conditions on its resources to alleviate the suffering of victims of a catastrophe and restore human dignity. ${ }^{5}$

Yet, there is an apparent contradiction in the positions of rising powers. Their increased development and peacebuilding roles in the early $2000 \mathrm{~s}$ reflected in part their desire to play a greater role on the world stage in order to democratize it. Thus, Brazil and South Africa are widely perceived to have expected some degree of support from new partner countries in their bids for permanent Security Council seats. Miguel Lengyel and Bernabé Malacalza (2011) point out the distinction between procedurally specific conditionalities on aid or technical cooperation, on the one hand, and implied or strategic conditionalities not tied specifically to aid but seen as part of a mutually supportive relationship on the other hand (Lengyel and Malacalza 2011, 15-16). Having denounced IMF conditionality on his own country and others, Brazilian President Lula embraced development and peacebuilding policies that did not include conditionality, for instance. Yet, this renunciation of strict conditionality in Lula's outreach to African countries can coexist with an expectation of partner countries' support on broader global questions. 
5. Mutual respect, equality, and cultural understanding.

There is an emphasis on cooperation that is seen as mutually beneficial, as aid that is seen as one (superior knowledge and tools) part coming to the aid of a (inferior knowledge and tools) party. The rising powers we have studied claim that their technical advice reflects an exchange among equals rather than that of a benefactor giving resources to a beneficiary. Indonesia emphasizes that this relationship is not a one-way transfer but involves mutual learning: Alexandra argues that "rather than acting as an expert conveying its success stories, Indonesia tends to apply a twoway approach in which it shares its own experiences, but also learns from the host country." Alexandra further finds that "Indonesia emphasizes a mutual learning process when conducting peacebuilding activities." One of the two principles Alexandra highlights in Indonesia's approach to peacebuilding is the "comfort" level of the partner country: "The host government should reach the stage where it feels the need for and is comfortable enough to open up itself to receiving other countries' assistance in the peacebuilding process." Sazak and his co-authors quote one Somali non-governmental organization (NGO) official which they think reflect the Somali view of Turkey's assistance: "When we work with Turkish organizations, we feel like equal partners. The Turks respect the Somalis as equals" (Interview with a Somali NGO representative, quoted in Wasuge 2016, 23).

\section{More technical cooperation rather than aid.}

One reflection of rising powers' emphasis on mutual respect and equality is a greater reliance on technical cooperation than the transfer of aid. Traditional donors use technical advisers extensively, including in security ministries, courts, and finance ministries. However, the amount of bilateral and multilateral aid and loans that traditional donors provide dwarfs the monetary value of their technical advisors. In contrast, rising powers draw on technical advisers and cooperation as a greater percentage of their peacebuilding work, usually bilaterally. In many cases, these advisers are sent to places of cultural, historical, or linguistic affinity, improving the chances that the exchange will be sustained. More research is needed to analyze the impact of South-South technical cooperation before we can judge if their approach is having the intended effects. 
Some partner governments and communities request or prefer Western aid, because it is perceived to result in more money or greater economic and social benefits for individuals or institutions involved, or because it addresses other political, economic or strategic interests (such as Myanmar seeking Western aid to counterbalance China's role). In addition, the reliance on technical advisers reflects a more constrained institutional and financial context than in many Western countries. It is less costly to pay the travel costs for one's own government employees to work abroad for six to 12 months than to provide aid for projects or pay the salaries and transaction costs of others. Brazilian law, for instance, provides for technical cooperation, but not for actual aid except through international organizations. Resource and legal constraints thus help explain the penchant for technical cooperation and for multilateralism.

\section{Monitoring, evaluation, and impact.}

Although more data are needed, rising powers also seem to differ from Western actors in the degree and character of their monitoring and evaluation of peacebuilding efforts. As seen earlier, rising powers' motives for peacebuilding reflect variously their humanitarian impulses, their ideologically-framed regional or global roles, their desire for neighborhood stability or their own interests in commerce or commercial and alliance or regional interests. It is worth reflecting on the strategic purposes of peacebuilding for rising powers. Western powers and traditional donors provide aid and peacebuilding support for strategic reasons of course. They seek stability in other regions and countries for their own security and to maximize commercial opportunities. They also seek to strengthen alliances and partnerships with other governments, and to propagate their values. For instance, a recent review commissioned by the Norwegian parliament, entitled "A Good Ally-Norway in Afghanistan 2001-2014," found that Norway's engagement with Afghanistan had achieved a strategic purpose of strengthening Norway's relationship with the United States, even as it largely failed to achieve virtually any of its project and programmatic goals on the ground in Afghanistan. ${ }^{6}$

Similarly, rising powers pursue peace-related programs for their own strategic reasons. These motives often reflect a desire to build relationships or strategic partnerships or trade relations. Such benefits rarely are captured by monitoring and evaluation frameworks. Yet to the extent that peacebuilding programs reflect strategic relationships or solidarity with 
countries in the global South, then those programs achieve their aims when relationships are strengthened. On a different level, the enhancement of legitimacy of a partner government is often viewed as strategic for an external donor as well as assisting legitimacy internally. In this view, the positive expression of senior Afghan officials about Indian projects is the most relevant criterion for success possible. Myanmar's governmental expressions of friendship and appreciation for Indonesia's role are more important to the foreign ministry than project-based evaluations.

Similarly, some rising powers acknowledge that their peace-related activities have a side effect of enhancing opportunities for commerce and investment by their own private sector. To the extent that these opportunities are seen as positive outcomes, they signify "successful" attainment of national interests quite apart from their impacts on peace. In addition, some rising powers' approaches center on long-term projects such as economic conditions and infrastructure.

Monitoring and evaluation of such projects will take years and not lend themselves to the sort of causal immediacy that conventional evaluation of short-term peacebuilding projects seek to ascertain. Instead, assessment will examine visible products like roads or schools completed, with less ability to identify connections to peace. The foreign ministries of rising powers have little culture of evaluation. Although their development agencies have growing monitoring and evaluation, they remain less institutionalized than their Western counterparts. Conventional project-based monitoring and evaluation are less commonly practiced by rising powers than traditional ones, but their governments are often more comfortable admitting how peace-related projects advance national interests.

Yet, assessment and learning are evident among rising powers. Several chapters note examples of an openness to incorporating effective elements of conventional practices, including adopting some practices that were earlier eschewed following a similar learning curve followed by traditional donors in past decades. After an avowed resistance to taking political considerations into its cooperation, for instance, China has in recent years recognized that it must heed issues of partisan and ethic exclusion or see its projects impeded. Turkey may yet confront some of the same problems encountered by Western powers of a military presence provoking perceived involvement favoring one side in Somalia. At the same time, Turkey has begun to recognize the need in Somalia for some degree of planning, coordination with other donors, and evaluation of its projects. And India is introducing ethical standards in its cooperation efforts. None of these 
rising powers is averse to multilateral approaches, but they are wary of seeing Western-led donor coordination processes become mechanisms to dictate the content of their assistance.

One arc of evolution and learning bears further research-how rising powers' peacebuilding activities redound on their internal policies regarding violence and insecurity. Abdenur and Call's chapter points out that Brazil's approaches to community violence and development in its peacekeeping mission in Haiti drew explicitly on the approaches of Viva Rio, a well-known NGO whose projects had helped improve household incomes and mitigate violence in Rio de Janeiro's most violent slums. Yet, there are few feedback mechanisms that draw on lessons from rising powers' peacebuilding activities abroad to shape policies at home. Few think tanks exist in these countries, and they have understandably focused on the relatively recent forays of some rising powers into peacebuilding abroad. They are not financially incentivized (by external or internal funders) to examine the implications of such activities for domestic policies, an endeavor that might also prove politically sensitive. Greater transparency public debate, and engagement with civil society and research communities might stimulate enhanced feedback loops between domestic and foreign experiences. Given high levels of poverty and insecurity in large swaths of rising powers' territories, their governments have also been hesitant to draw too much attention to sending their staff and money abroad.

\section{Conclusions}

This book seeks to identify and analyze the peacebuilding concepts, policies, and practices of a selected group of rising powers: Brazil, India, Indonesia, South Africa, and Turkey. Although the development practices of these new actors have been analyzed by scholars, their peacebuilding activities have not received much scrutiny. Our book finds a number of common elements, starting with different understandings of peacebuilding that bear further study and discussion. "Peacebuilding" for these countries is less narrowly understood than in Western settings or in the $\mathrm{UN}$, and incorporates development, humanitarian, infrastructure, health, education, jobs creation, mediation, dialogue, and reconciliation activities, as well as more conventional post-war reconstruction and institutional support. Their notion of "peacebuilding" covers pre-war, at-war, and post-war countries, as well as those experiencing mass violence that falls short of armed conflict. 
The peacebuilding policies and operations of these rising powers also reflect commonalities that distinguish them from traditional donors. They have a more holistic operational approach that draws on multiple ministries, including technical advisors from agriculture, health, and education sectors. They have a longer time horizon and strong emphasis on national ownership, often interpreted to mean governmental consent, than Western approaches. Their heightened sensitivity to sovereignty and a lack of immediate conditionalities on their peacebuilding cooperation, even when that cooperation advances strategic and economic interests, reflect their post-colonial trajectories and South-South solidarity. The limited scale of their funding and programs, as well as divergent political agendas among traditional donors and rising powers, combine to limit the extent to which peacebuilding policies and practice have evolved during their short lifetimes. However, important shifts in peacebuilding both converge with and have been influenced by the peacebuilding policies and activities of these countries as their roles have gained salience on the global stage.

A number of caveats are in order. First, it would be an exaggeration to say that the rising powers studied here represent all rising powers. This book systematically examined six important rising powers-Brazil, India, Indonesia, South Africa, and Turkey. These are all democratic countries whose recent (or not so recent in India's case) political transitions shape their regional and global roles and policies. Other countries that have become more active as development partners and peacebuilding actorsincluding Russia, China, Mexico, Colombia, Egypt, Nigeria, Saudi Arabia, and other Arab states, among others-are not analyzed here. These may have very different peacebuilding approaches that merit further study.

Second, although this book has identified some elements common to these countries, these countries exhibit variation among themselves in how they conceptualize and practice peacebuilding. Rising powers diverge, for instance, in the extent to which they equate peacebuilding with development. For most, peacebuilding is a distinct but related and overlapping concept with development. It is a particular peace-related set of activities that usually occur in the context of war-torn societies, and that aim to advance or sustain peace. India is an exception, as it equates virtually all of its development activity with peace support and peacebuilding. India, like China, also has a longer time horizon given its historical reference points; therefore, the longer-term emphasis means less concern with junctural political events and more concern with longer-term social 
and economic conditions for peace. Other variations exist in the extent to which countries contrast themselves explicitly with Western or traditional approaches, with Brazil being more prone to such statements, for example, than Indonesia.

Another area of variation among the rising powers is in the degree to which their cooperation is provided bilaterally versus multilaterally. One study shows that Turkey, Brazil, India, and Russia all shifted from bilateral assistance toward multilateral channels between 2005 and 2010 (White 2011, 7). Indonesia and China shifted in the opposite direction, and South Africa remained highly multilateral according to its official development aid figures (White 2011). Multilateral often does not mean working with and through the UN. These countries remain comfortable working in coordination with the UN, but this is not necessarily the preferred mode of cooperation. Rising powers have fostered work with and through regional organizations like the AU and ASEAN, partly because of greater influence in those fora. In addition, they work through multilateral groupings such as the BRICS and its New Development Bank, the India, Brazil, and South Africa (IBSA) fund, the AU's New Economic Partnership (NEPAD), the Organization of Islamic Cooperation (OIC) , the Brazilian Development Bank, and in the case of China, its Asian Infrastructure Investment Bank. Most of these mechanisms are relatively new, and hold additional potential to shape the peacebuilding priorities and financing.

Recent events raise doubts about whether rising powers will sustain their new roles in development and peace-related cooperation. Corruption indictments of senior officials have rocked the administrations of President Zuma in South Africa and sparked the impeachment of President Rousseff in Brazil. China has faced economic slowdown, and political crises plagued the government Recep Erdoğan in Turkey. Indonesia's development cooperation fell from $\$ 27$ million in 2012 to $\$ 12$ million by 2013. Brazil has cut the budget of its Ministry of Foreign Relations dramatically since 2013, slashing its program budgets (Charles Call interviews with Brazilian diplomats, August 2015, Brasilia). As a result, some scholars call into question the future impact of rising powers on global governance and international practices of development and peacebuilding (Chandhoke 2014; Quadir 2014; Stuenkel 2014).

What then can we say about the impact of these new peacebuilding roles in the institutions and policies and practice of peacebuilding globally? The dialogues and discussions thus far indicate that these rising 
powers have influenced the discourse and practices of development, but not transformed them. One area of apparent impact is the content of the SDGs, approved at the UN General Assembly in September 2015. Rising powers did not veto goals regarding peace and security, but they exercised important influence on the wording of those goals and targets, including Goal 16 on "just, peaceful, and inclusive societies." Rising powers helped shape Goal 16's "targets" to exclude the term "security" and to include capacity-building, commitment to a stronger role for developing countries in the institutions of global governance, violence prevention, and reduced illicit arms flows. Work on peacebuilding in the next 15 years will reflect these targets. Beyond the SDGs, rising powers have helped achieve more holistic notions of peacebuilding in policy statements that reinforce the work of development agencies and funds in this area. Their longer time horizons also support the role of the development and humanitarian actors in peacebuilding, in contrast to a narrower concept that privileges the UN's peace and security institutions.

The participation of rising powers in the peacebuilding architecture at the UN also contrasts with their reluctance to engage the OECD and its New Deal processes. Brazil has chaired the PBC, and Indonesia, India, and South Africa have all played prominent roles in PBC debates and decisions. That role has strengthened a commitment to national ownership in the rhetoric and work of the UN's peacebuilding work, including a tone of mutual respect in UN dealings with recipient governments. These countries' holistic notions have also helped ensure that economic recovery and jobs programs remain a part of the agenda of the UN peacebuilding and peacekeeping programming and discourse, including the UN Peacebuilding Fund. Their emphasis on national ownership has ensured a central place for that concept in all UN and other multilateral fora, visible also in the 2015 reviews of peace operations and peacebuilding. Their role has not, however, led to an end to conditionality. The tug-of-war between an expansive understanding of "national ownership" (as backed by Western donors) versus a narrow government-centered understanding of that term (reflecting usage by rising powers) persists in the UN.

Which direction, one might speculate, will the peacebuilding policies and engagement of the rising powers take in the coming years? At a workshop in The Hague in 2016, researchers debated whether the future would witness a convergence or persistent different tracks between traditional approaches and rising powers' approaches to peacebuilding. Much of that, of course, depends on the role and relative power of specific rising 
powers in global affairs in coming decades, discussed above. However, the role of partner countries themselves, and the understandings within multilateral institutions, will play an important role in determining whether and how alternative ideas will prevail in this mix. It is possible that some convergence will occur as traditional donors choose or are forced by the "development cooperation market" to accommodate longer timelines, less conditionality, more deference to governments. It is also possible that rising powers will "learn" to adopt more results-based and shorter-term approaches in response to their own domestic constituencies. They may also broaden their understandings of national ownership to include more NGOs. In the near term, distinct but overlapping parallel approaches are likely to persist. These need not be competitors, but may prove to be complementary and cooperative.

Ultimately, the impact of rising powers on peacebuilding institutions, policies, and practices is likely to derive more from their discourse, concepts, and moral authority as their resources. Their "talk" may influence more than their "walk," although the influence of their programs may vary depending on the resources devoted. From a partner government's perspective, a small alternative source of funding goes a long way to undercut conditionality even of a much larger donor. The research presented in this book documents how rising powers have set forth a common set of principles and rationales as the basis for a new approach to peacebuilding. That set of principles around the peacebuilding concept and its practice are likely to continue to serve as reference points for debates in the halls of Western donors, the UN and regional organizations, bolstered by nongovernmental organizations. The pace and character of those interactions will shape peacebuilding on the ground in varied and important ways in coming years.

\section{Notes}

1. Remarks of the Secretary-General to the Security Council Open Debate on "Maintenance of International Peace and Security: Conflict Prevention and Sustaining Peace," 10 January 2017, accessed on January 31, 2017, https://www.un.org/sg/en/content/sg/speeches/2017-01-10/ secretary-generals-remarks-maintenance-international-peace-and

2. See, for instance, the G7+ Fragility Assessment frameworks, the UK Stabilization Unit's Joint Analysis of Conflict and Stability, the State Department's Interagency Conflict Analysis Framework 2.0 (2013), 
USAID Conflict Assessment Framework 2.0 (2011), the UNDP Conflict-related Development Analysis (2007), inter alia.

3. The approach is similar to Samuel Huntington's Political Order in Changing Societies (Yale University Press, 1968), but less concerned with order in the core, and more concerned with order as pre-requisite for domestic prosperity, capacity, and eventually legitimacy.

4. Calculations of authors based on DPKO and DPA mandated missions, average length of existing missions at end of each year.

5. See also "Humanitarian Assistance by Turkey," Ministry of Foreign Affairs, accessed on 17 September 2015, http://www.mfa.gov.tr/ humanitarian-assistance-by-turkey.en.mfa

6. See "To Say It Like It Is: Norway's evaluation of its part in the international intervention," by Ann Wilkins, Afghanistan Analyst Network, accessed on 19 September 2016, https://www.afghanistan-analysts.org/ to-say-it-like-it-is-norways-evaluation-of-its-part-in-the-internationalintervention/, and "A good ally: Norway in Afghanistan," Christian Michelsen Institute, accessed on 19 September 2016, http://www.cmi. no/news/1711-a-good-ally-norway-in-afghanistan

\section{REFERENCES}

Abdenur, Adriana Erthal, and Danilo Marcondes de Souza Neto. 2014. Rising Powers and the Security-Development Nexus: Brazil's Engagement with Guinea-Bissau. Journal of Peacebuilding and Development 19(2): 1-16.

Achilles, Kathryn, Onur Sazak, Thomas Wheeler, and Auveen Elizabeth Woods. 2015. Turkish Aid Agencies in Somalia: Risks and Opportunities for Building Peace. Saferworld and Istanbul Policy Centre. Accessed from http://www.saferworld.org.uk/resources/view-resource/893-turkish-aid-agencies-insomalia-risks-and-opportunities-for-building-peace

Besharati, Neissan A. 2013. South African Development Partnership Agency (SADPA): Strategic Aid or Development Packages for Africa. Johannesburg: South African Institute for International Affairs (SAIIA).

Call, Charles T., and Katy Collin. 2015. The United Nations Approach to Peacebuilding. Paper prepared for "Rising Powers and Peacebuilding" project. www.risingpowersandpeacebuilding.org

Carmody, Pádraig R. 2013. The Rise of the BRICS in Africa: The Geopolitics of South-South Relations. Chicago: University of Chicago Press.

Chandhoke, Neera. 2014. Realising Justice. In Rising Powers and the Future of Global Governance, ed. Kevin Gray and Craig N. Murphy. New York: Routledge.

de Carvalho, Benjamin, and Cedric de Coning. 2014. Rising Powers and the Future of Peacebuilding. Oslo: NOREF. 
de Coning, Cedric, Thomas Mandrup, and Liselotte Odgaard, eds. 2015. The BRICS and Coexistence: An Alternative Vision of World Order. London: Routledge.

Fernández Jilberto, Alex E., and Barbara Hogenboom, eds. 2010. Latin America Facing China: South-South Relations beyond the Washington Consensus. New York: Berghahn Books.

Flemes, Daniel. 2007. Emerging Middle Powers' Soft Balancing Strategy: State and Perspectives of the IBSA Dialogue Forum. German Institute of Global and Area Studies Working Paper No. 57.

Hurrell, Andrew. 2006. Hegemony, Liberalism and Global Order: What Space for Would-Be Great Powers? International Affairs 82(1): 1-19.

Kok, Naomi. 2014. South Africa's Peacebuilding and PCRD Activities: The Role of IBSA and BRICS. ISS Paper. https://emergingpowerspeacebuilding.files. wordpress.com/2015/08/kok-south-africas-peacebuilding-and-pcrd-activities.pdf

Lengyel, Miguel, and Bernabé Malacalza. 2011. What do We Talk When We Talk about South-South Cooperation? The Construction of a Concept from Empirical Basis. Paper presented at IPSA-ECPR Joint Conference, São Paulo, February 16-19.

Leite, Iara Costa, Bianca Suyama, Laura Trajber Waisbich, and Melissa Pomeroy. 2014. Brazil's Engagement in International Development Cooperation: The State of the Debate. International Development Studies (Evidence Report No. 59).

Madlala-Routledge, Nozizwe, and Sybert Liebenberg. 2004. Developmental Peacekeeping. African Security Review 13(2): 125-131. doi:10.1080/102460 29.2004.9627292.

Mahmoud, Youssef, and Andrea Ó Súilleabháin. 2016. With New Resolutions, Sustaining Peace Sits at Heart of UN Architecture. IPI Global Observatory, New York, 29 April.

Martin, G. Eugene. 2010. Facilitating Peacemaking in Internal Conflicts: Lessons from the Philippines. Georgetown Journal of International Affairs 11(1): 73-80.

Mathur, Anita. 2014. Role of South-South Cooperation and Emerging Powers in Peacemaking and Peacebuilding. NUPI Report. https://emergingpowerspeacebuilding.files.wordpress.com/2015/08/mathur-role-of-south-southcooperation-and-emerging-powers.pdf

McDonald, Kara C., and Stewart M. Patrick. 2010. UN Security Council Enlargement and U.S. Interests. Washington, DC: Council on Foreign Relations.

Mody, Renu. 2011. South-South Cooperation: Africa on the Centre Stage. London, UK: Palgrave Macmillan.

Mullen, Rani. 2013. The State of Indian Development Cooperation. New Delhi: Centre for Policy Research. http://cprindia.org/sites/default/files/policybriefs/Spring_2014_IDCR_Report_the_State_of_Indian_Development_ Cooperation.pdf 
Nyuykonge, Charles, and Siphamandla Zondi. 2016. South African Peacebuilding Approaches: Evolution and Lessons. Paper prepared for "Rising Powers and Peacebuilding" project. www.risingpowersandpeacebuilding.org

Pouliot, Vincent, and Jean-Philippe Therien. 2015. The Politics of Inclusion: Changing Patterns in the Governance of International Security. Review of International Studies 41(02): 211-237.

Quadir, Fajimul. 2014. Rising Donors and the New Narrative of South-South Cooperation. In Rising Powers and the Future of Global Governance, ed. Kevin Gray and Craig N. Murphy. New York: Routledge.

Richmond, Oliver P., and Ioannis Tellidis. 2013. The BRICs and International Peacebuilding and Statebuilding. Oslo: NOREF. https://emergingpowerspeacebuilding.files.wordpress.com/2015/08/richmond-tellidis-brics-andinternational-peacebuilding-and-statebuilding

Santos, Rita, and Teresa Almeida Cravo. 2014. Brazil's Rising Profile in UN Peacekeeping Operations Since the End of the Cold War. Oslo: NOREF. https://emergingpowerspeacebuilding.files.wordpress.com/2015/08/ santos-brazils-rising-profile-in-un-peacekeeping.pdf

Schirm, Stefan A. 2012. Leaders in Need of Followers: Emerging Powers in Global Governance. In Power in the 21st Century: International Security and International Political Economy in a Changing World, ed. Enrico Fels, JanFrederik Kremer, and Katharina Kronenberg, 211-236. Berlin: Springer.

Stamnes, Eli. 2016. The European Union and Peacebuilding. Paper prepared for "Rising Powers and Peacebuilding" project. www.risingpowersandpeacebuilding.org

Stuenkel, Oliver. 2014. Rising Donors and the Future of Democracy Promotion: The Cases of Brazil and India. In Rising Powers and the Future of Global Governance, ed. Kevin Gray and Craig N. Murphy. New York: Routledge.

Tank, Pinar. 2013. Turkey's New Humanitarian Approach in Somalia. Oslo: NOREF. https://emergingpowerspeacebuilding.files.wordpress.com/2015/08/tankturkeys-new-humanitarian-approach-in-somalia-tank.pdf

United Nations, General Assembly. 2015. Transforming Our World: The 2030 Agenda for Sustainable Development, A/RES/70/1. http://www.un.org/ ga/search/view_doc.asp?symbol=A/RES/70/1\&Lang=E

van Nieuwkerk, Anthoni. 2014. South Africa and the African Peace and Security Architecture. Oslo: NOREF. https://emergingpowerspeacebuilding.files. wordpress.com/2015/08/van-nieuwkerk-south-africa-and-the-african-peaceand-security-architecture.pdf

Vieira, Marco Antonio, and Chris Alden. 2011. India, Brazil, and South Africa (IBSA): South-South Cooperation and the Paradox of Regional Leadership. Global Governance 17(4): 507-528.

Wasuge, Mahad. 2016. Turkey's Assistance Model in Somalia: Achieving Much with Little. Mogadishu: Heritage Institute for Policy Studies. 
White, Stacey. 2011. Emerging Powers, Emerging Donors: Teasing Out Developing Patterns. Report of the Center for Strategic and International Studies (CSIS). February. Washington, DC: CSIS.

Charles T. "Chuck" Call is Associate Professor of International Peace and Conflict Resolution at School of International Service, American University, Washington DC.

Cedric de Coning is a senior research fellow in the Peace and Conflict Studies Research Group at Norwegian Institute of International Affairs (NUPI), and a senior advisor on Peacekeeping and Peacebuilding for the African Centre for the Constructive Resolution of Disputes (ACCORD).

Open Access This chapter is licensed under the terms of the Creative Commons Attribution 4.0 International License (http://creativecommons.org/licenses/ by $/ 4.0 /)$, which permits use, sharing, adaptation, distribution and reproduction in any medium or format, as long as you give appropriate credit to the original author(s) and the source, provide a link to the Creative Commons license and indicate if changes were made.

The images or other third party material in this chapter are included in the chapter's Creative Commons license, unless indicated otherwise in a credit line to the material. If material is not included in the chapter's Creative Commons license and your intended use is not permitted by statutory regulation or exceeds the permitted use, you will need to obtain permission directly from the copyright holder.

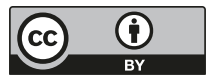

